\title{
The Development of Interactive Education Media to Improve Emotional Intelligence of Early Age Children in Raudhatul Athfal As-Syafiiyah
}

\author{
Hafsah$^{1}$, Edi Saputra ${ }^{2}$, Suryaniar ${ }^{3}$ \\ 1,2Faculty of Tarbiyah and Teacher Training, Universitas Islam Negeri Sumatera Utara, Indonesia \\ ${ }^{3}$ Postgraduate Program in Faculty of Tarbiyah and Teacher Training, Universitas Islam Negeri \\ Sumatera Utara, Indonesia \\ Email: Suryaniar78@gmail.com
}

\begin{abstract}
This researcher discusses the development of interactive educational media to improve emotional intelligence of young children in Ra As-Syafiiyah. This research aims to produce test instruments to measure the ability to increase emotional intelligence of young children in Ra As-Syafiiyah. Valid, practical and effective. The type of research used is research and development (RED), namely the development of interactive educational media. This interactive educational media development model was developed based on the ADDIE (Analysis, Design, Development, Implementation, and Evaluation) development model. The test subjects in this study were students of class A and class B at the Ra As-Syafiiyah School. The output of this interactive education media is in the form of apk files that can be installed easily, making it easier for students in the learning process. Based on the results of limited trials conducted, the data obtained from the expert validation results with an average of 3.5 are in the category of very valid, because $3 \leq M \leq 4$ so that the material on the media is said to be very valid, while the results of media expert validation with an average an average of 3.3 is in the very valid category, because $3 \leq M \leq 4$ so interactive education media is said to be very valid. While the validation results of linguists with an average of 3 are in the very valid category, because $3 \leq M \leq 4$ so interactive education media are said to be very valid. Effective because interactive education media is rated by students with positive responses with an average percentage of positive responses of students at $89.25 \%$ and average responses of 4.42 and teacher responses with an average response of 4.1 said to be effective because the percentage of student responses and teacher more than 50\%. Practical because the results obtained from the learning media implementation of $89.28 \%$ are said to be practical because the percentage of interactive educational media implementation is greater than $70 \%$.

Keywords: development; interactive learning media
\end{abstract}

\section{Introduction}

The rapid development of technology is currently influencing the learning process in early childhood education schools and also influencing the learning material as well as how to deliver the material in the process of teaching and learning activities. In the early childhood education stage, students will tend to be more interested in games that are easy to play and in which there are bright colors and animated images that attract attention. And in this stage students will more easily remember a form or writing that has attractive color features and communicative and fun shapes through learning media.

Interactive education media is a technology-based learning media that is very familiar with the world of children's play. Play is a direct and spontaneous activity in which a child uses other people or objects around him happily, voluntarily, and imaginatively, using his feelings, hands, or all parts of his body. 
Through interactive educational media, children will directly learn about emotional intelligence without realizing it. Through interactive education media it is hoped that children will be more interested in learning and also related to the development of children's emotional intelligence.

The development of information and communication technology in the Industrial 4.0 era has had a great influence on the teaching and learning process in the world of education, especially in higher education and universities (Syakur, 2017). Information technology can be accepted as a medium in conducting the educational process, including helping the teaching and learning process, which also involves searching for references and sources of information. (Shahroom in Syakur, 2020).

\section{Theoritical Review}

The term media comes from the Latin language and is a plural form of medium which means an intermediary or introduction (Putri et al., 2019: 2). Arsyad (2014: 6), explained that in learning activities often the use of the word learning media was replaced by terms such as hearing aids, instructional materials (audio-visual communication), education of visual aids (visual education), educational technology (educational technology), teaching aids and explanatory media. Suryani, et al. (2018: 5) states that learning media are all forms and means of delivering information created or used in accordance with learning theory, can be used for learning purposes in channeling messages, stimulating students' thoughts, feelings, concerns, and desires so that they can encourage the learning process intentional, purposeful, and controlled.

Sanjaya (2012: 219) learning through multimedia is learning that is designed by using various media simultaneously such as text, images (photos), films (videos), and others, all of which work together to achieve the learning goals previously formulated. Suyitno (2016: 102) explains that interactive learning media in the form of text, visuals, and simulations can help students gain more knowledge, understand deeper concepts, and know the applications of the science being studied.

The term emotional intelligence was introduced in 1990 by Peter Salovey of Harvard University and Jack Mayer of the University of New Hampshire to explain the emotional qualities that seem crucial to success. Emotional intelligence according to Goleman (2003: 45) is the ability to recognize our own feelings and the feelings of others, the ability to motivate yourself and the ability to manage emotions well in yourself and in relationships with others. Emotional intelligence not only serves to control themselves, but more than that too, reflects in managing ideas, concepts, works or products so that it is of interest to many people (Suharsono, 2004: 120).

Masnipal (2013: 117) explains some of the main characteristics of early childhood emotional emotional reactions, namely: (1) children are more likely to have disputes with peers, show a dislike of attitude (even though the range of hate is short), sulking (crying and hiding alone when scolded) ), sad if his favorite items are lost / dead, (2) activities are more intense friends, playing together at home or outside the home, family member relationships like kaka clashes are more frequent, because you are trying to show "strength" in front of family members. He wants to be recognized as one of the family members with the same rights, (3) the striking behavior is the behavior of anger / displeasure by hiding themselves while crying, the child must be recognized as part of the group / family, more intense meeting 
activities, disputes begin to decrease, (4) the interaction between children and peers is very intense, rarely fighting or working together longer, positive responses from adults make children close.

Hurlock (1978: 250) this emotional development is seen prominently in children aged 2.5 to 3.5 years, and 5.5 to 6.5 years. The development of emotions is influenced by maturity and learning. The characteristics of a child's social emotional reaction are as follows: (1) the child's emotional reaction is very strong, in terms of strength, the child's age increases, and the more mature the child's emotions, the child will be more skilled in having levels of emotional involvement, (2) emotional reactions often appearing on each occasion the way he wants. The more emotional children develop toward maturity, they will learn to control themselves and show emotional reactions in an environmentally acceptable way, (3) the child's emotional reactions are easily changed from one condition to another condition, (4) emotional reactions are individual, (4) the emotional state of the child can be identified through the behavioral symptoms displayed, (5) emotions can be known through behavioral symptoms. Children may not show emotional reactions directly, but they show indirectly through anxiety, daydreaming, crying, difficulty speaking, and nervous behavior, such as nail biting and thumb sucking, and (6) emotions often appear. Children often show increased emotion and they find that emotional outbursts often result in punishment, so they learn to adapt to situations that arouse emotions. Then they will try to curb their emotional outbursts or react in a more acceptable way.

\section{Research Methods}

This research uses research and development methods. The steps in making this module are carried out by following the Analysis, Design, Development or Production, Implementation or Delivery and Evaluation (ADDIE) development model. The subjects of the study were 40 students of RA As-Syafiiyah in class A and class B. The object of this study was the development of interactive educational media to improve emotional intelligence of young children. The research instrument was the product assessment sheet and questionnaire. The data analysis technique used is grouping categories based on assessment criteria.

\section{Discussion}

Product eligibility according to the material experts is obtained an average of 3.5 which is included in the valid category. The feasibility of the product according to media experts obtained an average of 3.3 which fall into the valid category. Product eligibility according to linguists is obtained an average of 3 that falls into the valid category.

The results of limited trials show the final results of student response questionnaire scores obtained a positive response percentage of $89.25 \%$ with an average response of 4.42 and an average teacher response questionnaire 4.1 which is very positive, so overall the interactive educational media that has been developed by the developer is very well known. Students and teachers also give an opinion on this media that this makes it easier for students to imagine and understand the contents of the material they see, because the material presented becomes clearer and not boring when playing it.

The aim of this design is to design an effective interactive educational media to improve emotionally of young children. At the age of 4-6 years, children begin to develop the ability to distinguish between what belongs or part of themselves and all the objects that he sees, hears, reads, touches, kisses when he begins to form a painting or picture of who he is. 
The child has also begun to develop the ability to distinguish between what belongs to or a part of him and all the objects he sees, hears, reads, touches, kisses when he begins to form a picture or picture of who he is. Children have basic abilities that they have had from an early age, including cognitive abilities, social-emotional abilities, religious moral values, physical motor skills, language skills and artistic abilities.

Emotional development that arises is that children will quickly learn to anger because anger is a simple and easy way to satisfy their needs. The development of children aged 4-6 years has the characteristics that the body becomes large, healthy and can participate in more activities and not easily tired. Success in using learning media in the learning process to improve learning outcomes depends on the content of the message, how to explain the message, and the characteristics of the recipient of the message. Thus in choosing and using media, these three factors need to be considered. The function of instructional media is more focused on two things, namely functions based on the media and its users. Basically the main function of learning media is as a learning resource. The uses of instructional media are to clarify the presentation of the message so as not to be too verbalistic, overcome the limitations of space, time and senses, the use of appropriate and varied learning media can overcome the passive attitudes of students, provide the same stimulant in learning, equalize experiences, and cause same perception.

Interactive education media is a media and content that uses a combination of different forms of content, multimedia also includes a combination of forms of content from text, audio, still images, animation, video, and interactivity. The use of computers to present and combine text, sound, images, animation and video with tools and connections so that users can navigate, interact, work and communicate can also be regarded as multimedia. Multimedia also describes electronic media devices used to store and experience multimedia content. The visual technique used is an illustration approach with imaginative and fantasy character designs to attract children's interests. The colors used are also diverse, bright colors and tertiary colors. Intrapersonal intelligence is very important to be developed in every individual from an early age. A person's intelligence can support their needs in dealing with environmental conditions and others in society. Every person is required to be able to know themselves before getting to know others, by knowing one's own personality, one can understand what should be done and what should not be done. Improving self-knowledge should be trained early. Material created in the media helps children to get to know what they are aspiring for, hobbies they have, children can express themselves better, can communicate well, imagine in making a story, and can control their emotions when involved in a problem condition to help improve children's intrapersonal intelligence.

The lack of knowledge about intrapersonal intelligence also influences the availability of suitable media to develop it, therefore it is made a media that can introduce and help increase intrapersonal and emotional intelligence of children. Seeing the potential of the child and existing problems, it is needed a media that can support improving children's intrapersonal intelligence early on. Media is made so that children can learn more fun and create reciprocal relationships with parents. The creative purpose of the learning media that will be created is to apply several ways as learning to develop knowledge about intrapersonal intelligence in early childhood through interactive learning media based on mobile application media. Seeing the age of the very young target audience, which is 4-6 years old, the design of interactive educational learning media is made by adjusting the thinking ability of the target audience. the ability to think and capture the intended message on the media is supported by the images and colors used and the display of sound and video in it. 
Designing an interactive educational media as one of the interactive learning media that can be used by teachers and students in the learning process is intended so that students can learn independently. The beginning of making this interactive educational media is to help students get to know land animals that are often found so that students or early childhood are more familiar with the animals that exist in this world. In making this interactive educational media, there are several obstacles experienced, including: (1) the media design process that will be developed which takes a long time, by considering various things, so that the interactive education media is completed in quite a long time, (2) developer knowledge is still limited about the operation of interactive educational media so in making this media, developers learn by relying on manual books made by researchers whose contents are complete on how to use interactive education media introduction of land animals, and (3) programming languages in this interactive educational media that quite difficult to be learned by developers, but can be learned, interactive educational media created with Android programming.

Based on the initial product that has been made, the material expert, media expert and linguist are tested, then a revision is made based on the assessment and comments from the experts. Products that have been revised are then continued to the limited test phase of 40 students from two classes A and class B. The results of this limited test get very good results, students feel happy and excited in learning the interactive education media. The enthusiasm of students was seen when they saw the educational game and saw the introduction of animals, students became more excited in doing exercises in the educational game menu and wanted to know more about land animals in the animal recognition menu. because according to students this interactive education media looks interesting, and so it's easier to introduce land animals, as evidenced from the student response questionnaire sheet with the results of positive responses from all students with the lowest percentage of positive responses is 80.49 , and the teacher's response with the percentage of positive responses of $100 \%$ with an average response of 4.1 which means the response is very positive. Then a final revision is made to create the final product. As with other interactive education media, this interactive education media is one of the interactive educational media that can be used in the process of learning animal recognition providing many benefits for students and students.

Therefore, based on research conducted through tests on the use of interactive educational media products, it has several advantages, including: (1) learning becomes more interesting and enjoyable because it uses new interactive education media known by students so that makes students interested and excited when using media the learning. In addition, time constraints, because this interactive educational media is made using language that is easily understood by students and is equipped with elements contained in interactive educational media such as illustrations, examples of educational games, animal recognition, (2) this interactive educational media can used for the introduction of land animals, (3) interactive educational media can be accessed not only on computers but also can be accessed on several other types of gadgets such as smartphones, iPad, Tablets, and (3) this interactive educational media in the form of apk application files so that it is easier to facilitate students in the use of interactive education media everywhere.

\section{Conclusions}

The conclusions of the study are as follows: (1) the process of developing interactive educational media to improve emotional intelligence of young children begins by conducting interviews with teachers and students in class. Furthermore, the design phase, researchers began designing interactive education media by considering the results of these observations, and making interactive education media The next stage is the development stage, after the 
interactive education media is designed by the developer, then it will be validated by experts, in this case material experts, media experts and linguists, then the experts give suggestions for improvement and then the developer revises the media. After the media is declared valid by material experts, media experts and linguists, then it goes to the implementation stage, namely a limited trial to 40 students from two classes A and class B, after testing students and teachers are given a questionnaire sheet to assess and provide suggestions for media interactive education. Then the last stage is the evaluation stage after being tested, the learning media will be evaluated, (2) the results of the validation of material experts with an average of 3.5 are in the very valid category, because $3 \leq \mathrm{M} \leq 4$ so the material on the media is said to be very valid , while the results of the validation of media experts with an average of 3.3 are in the very valid category, because $3 \leq \mathrm{M} \leq 4$ so that the learning media is said to be very valid, while the results of the validation of the language expert with an average of 3 are in the very valid category, because $3 \leq \mathrm{M} \leq 4$ so interactive education media is said to be very valid. Effective because interactive education media are rated by students with positive responses with an average percentage of positive responses of $89.25 \%$ with an average response of 4.42 and teacher responses with an average response of 4.1 said to be effective because the percentage of student responses more than 50\%. Practical because the obtained results of the learning media implementation of $89.28 \%$ are said to be practical because the percentage of interactive educational media implementation is greater than $70 \%$.

Recommendations that can be given are: (1) For Parents It is recommended for parents to often introduce animals early on so that children can explore, add experiences, and new insights to improve the emotional self of the child with interactive education media, children can be even more excited in get to know land animals because there are so many choices menu, (2) For teachers it is recommended to have creativity and innovation or the ability to create something new, either really new things or new ideas obtained by connecting several things that already exist and make it a new thing. So that the process of learning activities increases for the better, (3) for the Principal to facilitate learning in order to facilitate the teacher in providing understanding in the cognitive aspects also facilitate children in the learning process and the teacher can innovate more learning and creativity more, and for other researchers in order to research with the development of interactive educational media to improve emotional intelligence of early childhood with shapes and sizes that are more varied in increasing emotional intelligence of other early childhood such as: the ability to speak and the ability to interact with others.

\section{References}

Ananda, Rusydi. (2019). Desain Pembelajaran. Medan: LPPPI.

Arsyad, Azhar. (2014). Media Pengajaran, Jakarta: Raja Grafindo Persada.

Goleman, Daniel. (2002). Emotional Intelligence: Kecerdasan Emotional. Mengapa El Lebih Penting Dari Pada Iq. Jakarta: Gramedia.

Hurlock, Elizabeth. B. (1978). Child Development 4th Edition, New Jersey: McGraw Hill Inc. Moeslichatoen. (2004). Metode Pengajaran Di Taman Kanak-Kanak. Jakarta: Rineka Cipta.

Sanjaya, Wina. (2012). Strategi Pembelajaran Berorientasi Standar Proses Pendidikan,. Jakarta: Kencana Prenada Media:

Suryana, Dadan. (2018). Stimulasi Dan Aspek Perkembangan Anak. Jakarta: Bumi Aksara.

Syakur, A. (2020). The Effectiveness of Reading English Learning Process Based on Blended Learning through "Absyak" Website Media in Higher Education. Budapest International Research and Critics in Linguistics and Education (BirLE) Journal. P. 763-772 